\title{
Konstrukcje drewniane w architekturze sakralnej dawniej i dziś
}

\author{
Wojciech Mielnik \\ Wydziat Architektury,Politechnika Gdańska,e-mail:wojciech.mielnik@qplan.pl
}

Streszczenie: Drewniana architektura sakralna miała i ma duże znaczenie dla rozwoju budownictwa oraz jego walorów estetycznych. Zakorzeniona w tradycji ogniskuje w sobie cechy egzystencji człowieka, takie jak duchowość, kultura czy technika, zmaterializowane przy użyciu najlepszych tworzyw oraz wiedzy i umiejętności budowniczych. To „duchowość okryta drewnem”. Obiekty wernakularne zapisane w przestrzeni nie tylko budują obraz minionych czasów, ale również kształtują tożsamość miejsc oraz żyjących w nich ludzi. Stanowią także determinantę i punkt odniesienia dla twórczej kreacji współczesnych architektów. Świątynie wznoszone obecnie są przykładem różnorodności form przy zastosowaniu dużego wachlarza typów konstrukcji, co daje nieograniczone możliwości ich projektantom.

Słowa kluczowe: drewno, konstrukcja, obiekty sakralne, kościół, świątynia.

\section{Wprowadzenie}

Drewno jest naturalnym materiałem wykorzystywanym przez człowieka od początków jego poczynań w tworzeniu własnej przestrzeni. Na terenach Polski bogactwo lasów dawało schronienie, bezpieczeństwo i utrzymanie swoim gospodarzom. Różnorodność drzewostanu jest głównym atutem naszych lasów, a dbałość o ich utrzymanie i równowage w gospodarce leśnej jest priorytetem leśników. Pozyskiwane drewno służy głównie jako budulec, ze względu na swoje właściwości konstrukcyjne i stosunkową łatwość obróbki. Cechy drewna pozwalają na wykorzystywanie jego potencjału w sposób intuicyjny na wszelakie sposoby, a przede wszystkim do wznoszenia budynków. Przekazywany z pokolenia na pokolenie kunszt ciesielski wyrasta z tradycji lokalnej, a rozwijając się, podkreśla tożsamość regionu i ludzi go tworzących.

Charakterystycznym przykładem budownictwa drewnianego zakorzenionego $\mathrm{w}$ tradycji jest architektura sakralna. Świątynie ogniskują w sobie takie cechy egzystencji człowieka, jak duchowość, kultura czy technika, a wszystko to zmaterializowane przy użyciu najlepszych tworzyw oraz wiedzy i umiejętności - „duchowość okryta drewnem”. Potrzeba tworzenia coraz wznioślejszych budowli sakralnych stymulowała rozwój rozwiązań konstrukcyjnych.

\section{Krótka charakterystyka drewna wraz z przedstawieniem rozwoju elementów konstrukcyjnych}

Gatunki drzew najczęściej wykorzystywane do pozyskiwania materiału to przede wszystkim sosna, świerk i jodła, z których otrzymujemy drewno miękkie, oraz dąb i akacja dające drewno twarde. Drzewo rosnące składa się z korzeni, pnia i korony. Pień stanowi o ilości drewna, które jest materiałem nie jednorodnym, typowo różnokierunkowym (anizotropowym), zmieniając wygląd i cechy fizyczne w zależności od przekroju. Drewno składa 
się z masy twardzielowej i bielastej znajdującej się na pniu pod korą między miazgą a rdzeniem. Jego parametry ściśle powiązane są z gatunkiem drzewa i procesem jego wzrostu.

Jedną z bardzo ważnych zalet drewna jest jego duża wytrzymałość na ściskanie i rozciąganie przy niedużym ciężarze właściwym. Jednak ten surowiec ma również sporo wad. Zalicza się do nich głównie nieprawidłowości budowy powstające w okresie wegetacji drzewa oraz wskutek niewłaściwego składowania drewna. Obniżenie mechanicznych właściwości drewna jest efektem chorób drzewa czy ataków szkodników. Wreszcie drewno jest materiałem łatwopalnym i wymaga specjalistycznych zabezpieczeń. Biorąc pod uwagę wszystkie właściwości drewna, zarówno mechaniczne jak i techniczne, przeważają w nich zalety pozwalające na racjonalne wykorzystanie go jako materiału budowlanego. Uwzględniając ciągły rozwój środków ochrony oraz prawidłowy dobór surowca, mamy możliwość przedłużenia żywotności konstrukcji drewnianej. Ważny jest również aspekt ekologiczności drewna jako odnawialnego surowca wykorzystywanego w globalnej gospodarce.

Kształt budynku - od pierwotnego szałasu - ewoluował i osiągnął bardzo stabilny układ konstrukcyjny, jak na rys.1. W budynku możemy wyodrębnić trzy główne elementy: dach, ściany i fundamenty. Każdy z tych elementów rozwijał się w różnym czasie, osiągając optymalną formę. Posadowienie budynków uzależnione było przede wszystkim od rodzaju gruntów. Na terenach o podłożu zwartym i stabilnym często stawiano podwaliny budynków bezpośrednio na gruncie, lecz najczęściej wykonywano fundamenty z głazów stawianych punktowo lub układanych obwodowo. Na gruntach mniej nośnych lub na terenach podmokłych stosowano wbijane pionowo drewniane pale. Rozwój ścian osiągnął dość szybko swą optymalną formę w postaci konstrukcji sumikowo-łątkowych - rys.2 oraz wieńcowych (zrębowych) - rys. 3. Konstrukcje te różnią się cechami statycznymi. Pierwszy typ ścian jest sztywniejszy w układzie pionowym, a drugi w układzie poziomym. Dla usztywnienia ścian przed wyboczeniem stosuje się czopowanie. Ściany zrębowe spina się lisicami, co pozwala na zwiększenie ich wysokości. Budowniczowie borykali się dość długo z rozporem dachu, co stanowi istotny problem konstrukcyjny. Poszukiwali zatem rozwiązań w konstrukcjach sochowych czy slegowych. Rozwiązanie problemu znaleźli, stosując belkę wiązarową (stropową) spinającą krokwie. Dalszy rozwój więźb dachowych był modyfikowany, w zależności od rozstawu i kąta nachylenia połaci, przez dodawanie kolejnych elementów konstrukcyjnych.

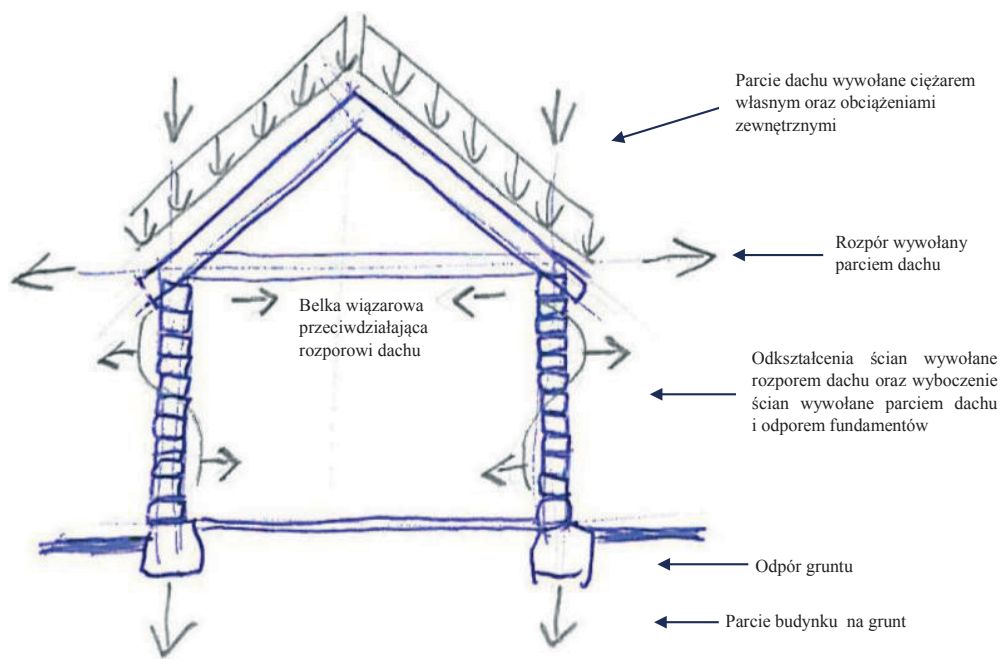

Rys. 1. Schemat układu sił w konstrukcji drewnianej 


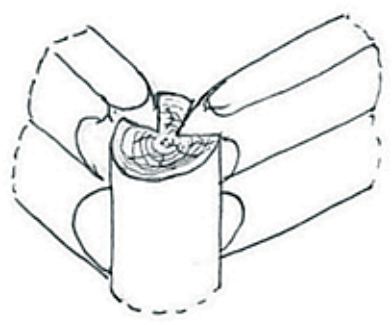

Rys. 2. Konstrukcja sumikowo-łątkowa

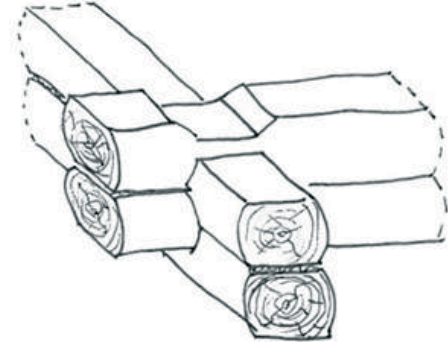

Rys. 3. Konstrukcja zrębowa

\section{Ukazanie przebiegu rozwoju budownictwa drewnianego na przykładzie obiektów sakralnych na terenach Polski, wraz z przedstawieniem rozwoju ustrojów i typów konstrukcji}

Obiekty sakralne swoją skalą i stopniem skomplikowania determinowały rozwój budownictwa drewnianego. Można wyodrębnić kilka etapów rozwoju konstrukcji drewnianej. Budowle drewniane należą do najstarszych konstrukcji wykonywanych w Polsce, co zostało potwierdzone wykopaliskami archeologicznymi w Biskupinie.

W źródłach pisanych zachowały się wzmianki o pierwszych kościołach drewnianych na terenach Polski z czasów piastowskich. Fragmenty takich budowli odsłoniły odkrycia archeologiczne w Krakowie, Kaliszu czy Jazdowie (dzisiejsza Warszawa). W tych budynkach dominowały dwa typy konstrukcji, choć pojawiały się również świątynie o konstrukcji mieszanej. Pierwszy typ to konstrukcja sumikowo-łątkowa, w której łączono wyżłobione łątki z układanymi poziomo sumikami pasowanymi w wyżłobienie - rys.2. Ten typ konstrukcji dawał zwiększoną sztywność w układzie pionowym przez zastosowanie łątek jako pionowych elementów spinających narożniki budynków oraz w miejscach otworowania ścian i ich połączeń. Całość posadowiono na belce podwalinowej, ściany wypełniono sumikami, zaś elementem wieńczącym była belka oczepowa spinająca obwodowo całość. Tworzyło to spójny układ konstrukcyjny, pod warunkiem prawidłowego fundamentowania budynku, bowiem głównym problemem było wysuwanie się sumików z wyżłobień narożnych łątek po utracie prawidłowej geometrii fundamentów.

Konstrukcja sumikowo-łątkowa jest protoplastą późniejszych układów szkieletowych. Druga to konstrukcja zrębowa polegająca na prostym lecz skutecznym połączeniu węgłów na obłap z okrąglaków -rys.3. Składa się ona wyłącznie z poziomych belek, co daje dużą sztywność w układzie poziomym. Bazowa belka-podwalina jak w poprzednim typie konstrukcji przekazuje cały ciężar budynku na fundamenty. Kolejne belki (płazy) układane jedna na drugiej spinane w narożnikach zamkami dają dobrą sztywność. Jedynie przy otworowaniu ścian (drzwi, okna) pojawiają się pionowe elementy łączące przecięte poziome belki. Ściany tego typu miały tendencje do wyboczenia.

Rozwój budownictwa sakralnego związany był z wydarzeniami religijnymi, politycznymi i ekonomicznymi. Po Soborze Laterańskim w 1215 r. Kościół, chcąc ułatwić wiernym uczestnictwo w liturgii, rozpoczął tworzenie nowych parafii. Fakt ten zbiegł się ze wzrostem zamożności społeczeństwa w czasach panowania Jagiellonów oraz Rzeczpospolitej Obojga Narodów. Fundowane wówczas kościoły powstawały pod wpływem estetyki gotyku, który wyodrębnił wyspecjalizowaną grupę budowniczych cieśli. Zaczęli oni rozwijać połączenia ciesielskie oraz usztywniać ściany przez czopowanie, co można nazwać kolejnym etapem rozwoju budownictwa drewnianego, $\mathrm{z}$ budownictwa intuicyjnego na rzemieślnicze. 
Ciągły rozwój konstrukcji drewnianej dokonywany przez optymalizację układu, zmiany geometrii czy połączeń ciesielskich pozwalał na coraz śmielsze rozwiązania oraz większe rozpiętości. Od XIII w. zaczęto stosować na ziemiach polskich konstrukcje szkieletowe. Technika ta przybyła z zachodniej części Europy. Charakteryzowała się gęstszym układem słupów spiętych dołem belką podwalinową a górą oczepem. Całość ścian stężona była ryglami i zastrzałami. Szkielet ścian wypełniano różnymi materiałami, zależnie od ich dostępności. Konstrukcje wypełnione żerdziami oblepionymi gliną nazywamy „strychulcem”, a wypełnione gliną zmieszaną z sieczką lub innym roślinnym materiałem - „konstrukcją szachulcową”. Ściany wypełnione cegłą nazywamy „ryglówką”. Świątynie wznoszone $\mathrm{w}$ tej technologii początkowo pojawiały się tylko w zachodnich i północnych regionach Polski, stopniowo rozpowszechniając się w całym kraju. Rozwój technik ciesielskich umożliwił powstawanie coraz to bardziej okazałych budowli sakralnych o każdym typie konstrukcji. Po XVI w. w kościołach zaczęto wykonywać okazałe sygnatury, rozbudowane soboty czy stawiać wieże po zachodniej stronie, a część prezbiterialna (wschodnia) często była wydzielona niższym zadaszeniem. W następnym stuleciu wprowadzano zmiany estetyczne nawiązujące do baroku, które początkowo ograniczały się tylko do elementów wystroju, nie zmieniając układu świątyń.

Etap architektury wernakularnej zakończył się wraz z zaangażowaniem się architektów w kształtowanie drewnianej przestrzeni sakralnej. Rozpoczął się czas twórczości do tej pory zarezerwowanej dla obiektów murowanych, co nie znaczy, że budownictwo anonimowe zniknęło, gdyż istniało równolegle i rozwijało się w swoim tempie. Nowe rozwiązania techniczne wprowadzane do konstrukcji drewnianej były kolejnym krokiem rozwoju. Zaczęto dodawać stalowe elementy wzmacniające i poprawiające właściwości drewna. Na XVIII w. przypada rozkwit architektury barokowej, która przyniosła zmiany układu przestrzennego kościołów drewnianych. Pojawiły się transepty przekryte kopułami na skrzyżowaniu naw oraz układy centralne budowane na planie krzyża greckiego. Rozpowszechniającym się układem była trójnawowa bazylika lub pseudo bazylika na planie krzyża łacińskiego, o stropach kolebkowych lub płaskich, z fasetami przyozdobionymi coraz częściej detalem rokokowym.

W okresie zaborów dominującym nurtem stał się historyzm kształtowany pod wpływem państw zaborczych w stylu bizantyjsko-ruskim i norwesko-niemieckim. Efektem tego było pojawienie się neogotyku, który charakteryzował się wyeksponowaną więźbą dachową oraz innymi historyzującymi elementami.

Od połowy XIX stulecia polscy architekci starali się stworzyć styl narodowy wzorowany na tradycji budownictwa drewnianego i murowanego. Stanisław Witkiewicz stał się twórcą stylu zakopiańskiego nawiązującego do budownictwa drewnianego Podhala. W 20-leciu międzywojennym opierano się na wzorcach stylu zakopiańskiego, modyfikując go o współczesne motywy przy użyciu tradycyjnych połączeń ciesielskich. Równolegle rozwijała się architektura sakralna pozostająca pod wpływem modernizmu, gdzie stosowano coraz częściej nowe zdobycze inżynierii. Przełom rozwoju konstrukcji drewnianej można określić na koniec XIX wieku, kiedy zastosowano pierścienie stalowe do złączy. Udoskonalenia techniczne polegały na zastosowaniu złączy inżynierskich, które z czasem zaczęły zastępować tradycyjne połączenia ciesielskie. Dla zwiększenia rozpiętości budowli i zarazem zmniejszenia jej ciężaru własnego zaczęto używać kratownic lub belek pełnościennych ze środnikiem z desek. Tego typu konstrukcje stosowano głównie w budynkach przemysłowych i obiektach inżynierskich.

Okres drugiej wojny światowej spowodował całkowite wyhamowanie budownictwa sakralnego, a zniszczenia wojenne pochłonęły bezpowrotnie wiele zabytków drewnianej architektury sakralnej. Nowa rzeczywistość powojenna Polskiej Rzeczpospolitej Ludowej 
nie sprzyjała Kościołowi, a działalność budowlana ograniczała się głównie do odbudowy nielicznych świątyń drewnianych. Nowo powstałe drewniane obiekty sakralne były przeważnie tymczasowymi kaplicami przed budową głównego kościoła.

Ważnym momentem w rozwoju konstrukcji drewnianych było wynalezienie nowych rodzajów klejów, co zwiększyło możliwości konstrukcyjno-technologiczne przez zastosowanie nowego materiału - drewna klejonego warstwowo. Połączenie wyselekcjonowanych lameli (desek o równomiernej budowie pozbawionych wad) złączem klejowym, stworzyło materiał stosunkowo jednolity pod względem wytrzymałościowym i pozwalający na dość swobodne kształtowanie formy. W odróżnieniu od wszystkich innych złączy, złącza na klej przekazują siły nie za pośrednictwem miejscowego docisku drewna, ale poprzez pracę stwardniałej błony klejowej. Złącza takie nie powodują również miejscowego osłabienia łączonych elementów. Zarówno właściwości mechaniczne jak i techniczne nowego materiału pozwalają na szerokie zastosowanie w konstrukcjach budowlanych. Drewno klejone w Polsce zostało zastosowane po raz pierwszy przez Przedsiębiorstwo Wielkowymiarowych Konstrukcji Drewnianych w Cierpicach.

\section{Przykłady współczesnej drewnianej architektury sakralnej}

Współczesne świątynie są przykładem różnorodności form i typów konstrukcji, pozwalających kształtować przestrzeń w dowolny sposób. Najbardziej popularnymi drewnianymi konstrukcjami stosowanymi w obiektach sakralnych są właśnie elementy z drewna klejonego warstwowo. Jest to bardzo atrakcyjny materiał ze względu na możliwość gięcia oraz duże rozpiętości uzyskiwane bez konieczności pośrednich podpór. Za coraz częstszym stosowaniem tej konstrukcji w kościołach przemawiają nie tylko parametry techniczne, ale również walory estetyczna i użytkowe. Dzięki klejeniu warstwowemu drewno powróciło do łask w powszechnym stosowaniu.

Poniżej przedstawiono przykład kościoła w układzie bazylikowym trójnawowym o konstrukcji mieszanej. Ściany osłonowe wzniesiono w technologii murowej, a główną konstrukcję wykonano z drewna klejonego warstwowo. Zarówno belki dachowe jak i słupy nawy głównej wraz z nawami bocznymi wykonano w tej technologii. Gięta forma belek zwieńczających główną nawę przypomina gotyckie łuki, nadając wnętrzu dostojeństwa. Zastosowany materiał jest ciepły w odbiorze i daje wrażenie lekkości formy.

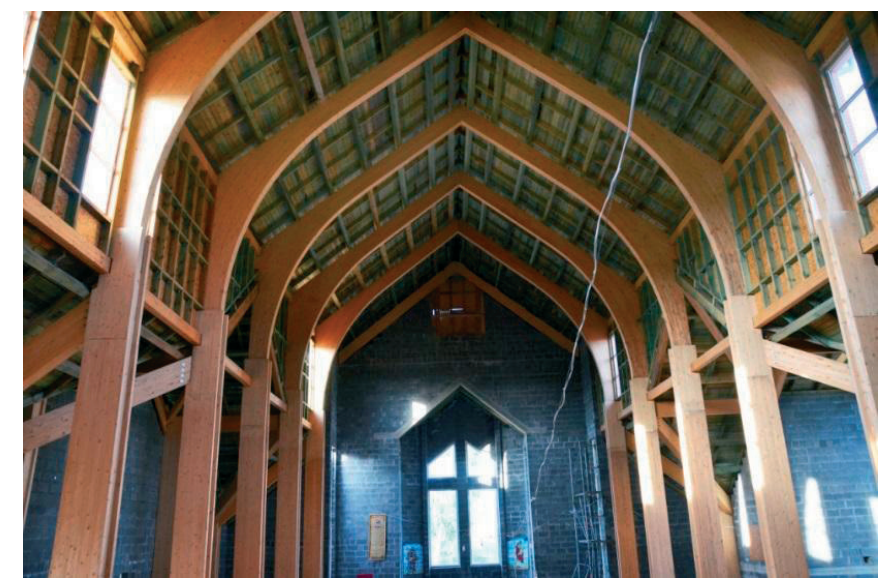

Fot. 1. Kościół pod wezwaniem Świętych Apostołów Szymona i Judy Tadeusza w Chwaszczynie. Architekt: dr inż. arch. Jerzy Kaczorowski, foto: Wojciech Mielnik 
Tradycja wznoszenia drewnianych budynków przetrwała w południowej części kraju. Coraz większą popularnością cieszą się tam domy z bali o konstrukcji zrębowej. Tradycyjna ciesiołka z wykorzystaniem współczesnych technologii pozwala na wznoszenie obiektów spełniających dzisiejsze warunki techniczne zawarte w prawie budowalnym. Tego typu konstrukcje wykorzystywane są głównie w domach mieszkalnych, nie tylko tych o tradycyjnej formie, lecz również o współczesnych bryłach. Drewniane obiekty sakralne wykonywane są rzadziej.

Poniższy przykład przedstawia współczesny kościół wybudowany w 2007 r. przez podhalańskich cieśli z jodłowych bali, tzw. płazów, o konstrukcji zrębowej i dachu kalenicowym krytym gontem. Nad wejściem głównym znajduje się wieża słupowa o wys. 14 m, która podkreśla karpacki styl budowli.
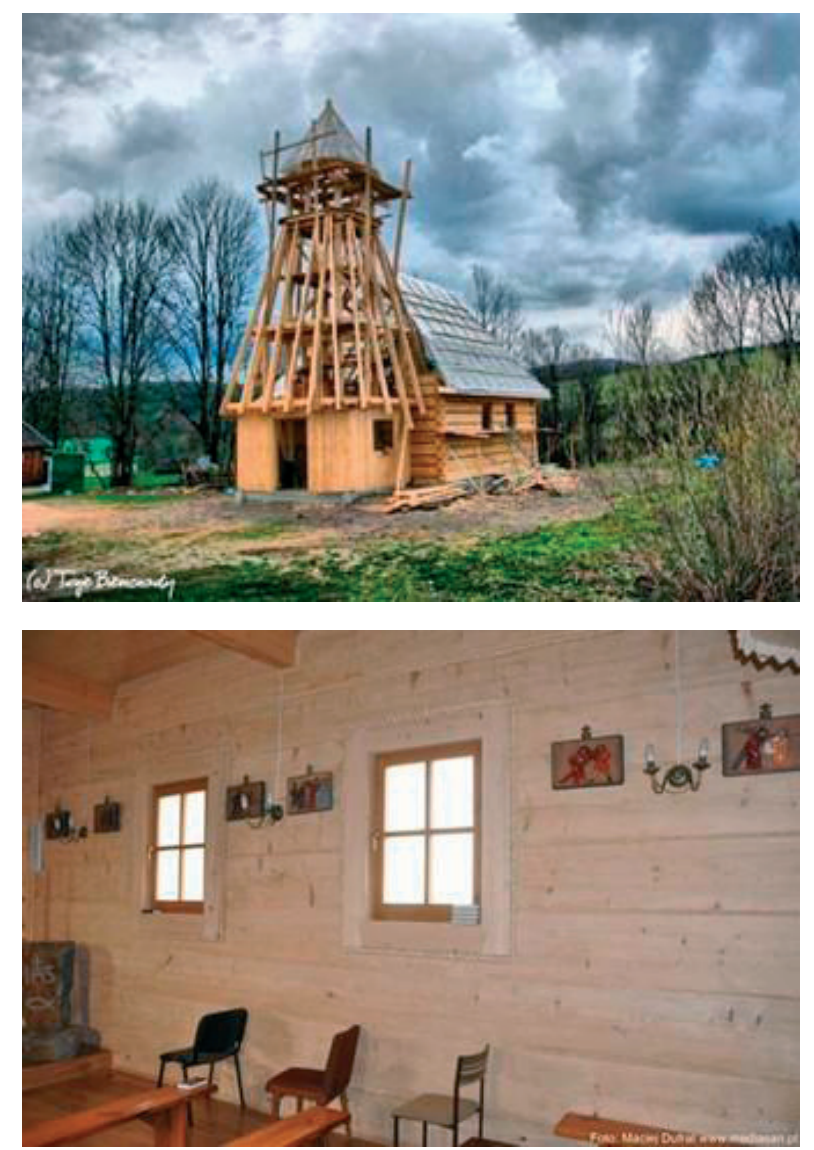

Fot. 2,3. Kościół pw. Najświętszej Maryi Panny Częstochowskiej w Woli Michałowej Autor projektu: inż. Bogdan Jezierski, foto: P. Szechyński

Kolejną tradycyjną drewnianą konstrukcją stosowaną w budownictwie jest konstrukcja szkieletowa. Ten typ występuje sporadyczne, lecz coraz częściej. Obecnie wykorzystuje się również prefabrykacje takich konstrukcji, co zapewnia ich szybki montaż.

Kościół w Zamościu koło Bydgoszczy ma mieszaną konstrukcję drewnianą. Jego część nośna to konstrukcja ciesielska, szkielet słupowo ramowy z pełnych słupów, belek i krokwi sosnowych, natomiast wypełnienie ścian wykonano w konstrukcji szkieletu 
deskowego. Słupy zewnętrzne elewacji frontowej, słupy podpierające we wnętrzu strop chóru oraz podpory dachu nad prezbiterium, które akcentują je architektonicznie, wykonano z daglezji.

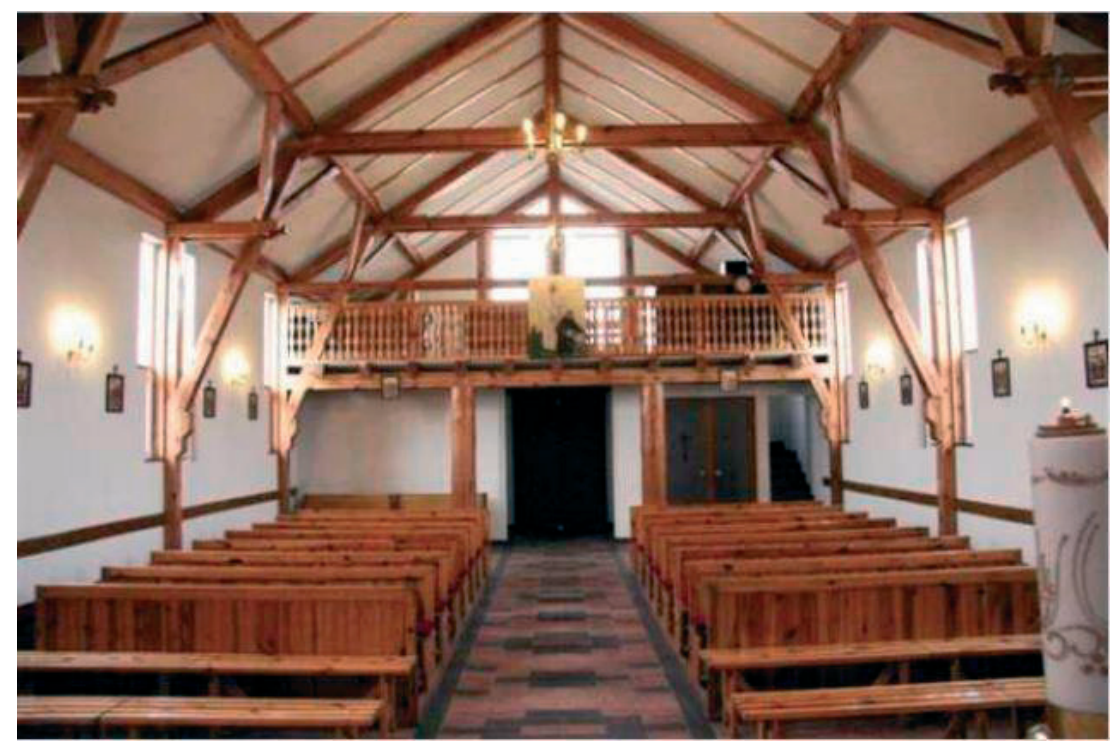

Fot. 4. Kościół pw. Świętego Ojca Pio w Zamościu koło Bydgoszczy. Autor: mgr inż. arch. Paweł Władysław Kowalski, foto: Paweł Władysław Kowalski

Jednym z najbardziej rozpowszechnionych typów konstrukcyjnym w budownictwie drewnianym są obiekty wznoszone w technologii lekkiego szkieletu tzw. konstrukcji kanadyjskiej. Konstrukcja ta charakteryzuje się gęstym rozstawem słupków i wiązarów dachowych, co $60 \mathrm{~cm}$. Ściany są spięte u dołu pojedynczą podwaliną, a u góry podwójnym oczepem. Do technologii tej wykorzystywane jest drewno o niewielkim przekroju, co pozwala na łatwy i szybki montaż. Mimo rozwiniętej technologii montażu i dopracowaniu schematów konstrukcyjnych, zastosowanie tej konstrukcji jest sporadyczne. W budownictwie sakralnym ogranicza się głównie do tymczasowych kaplic stawianych przed budową głównego kościoła lub niewielkich obiektów kultu. Poniższy projekt jest próbą ukazania możliwości wykorzystania tej konstrukcji.

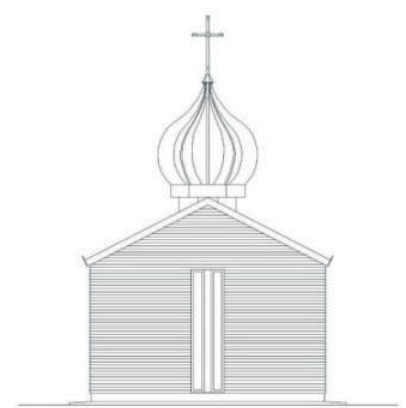

Rys. 4. Elewacja

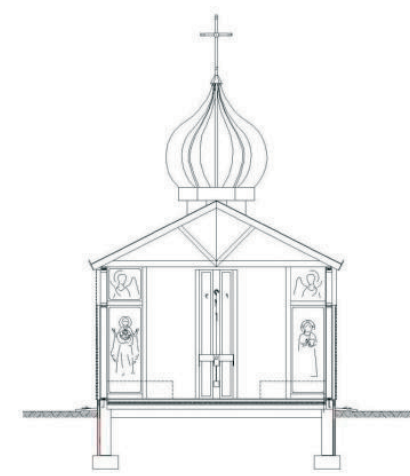

Rys. 5. Przekrój 


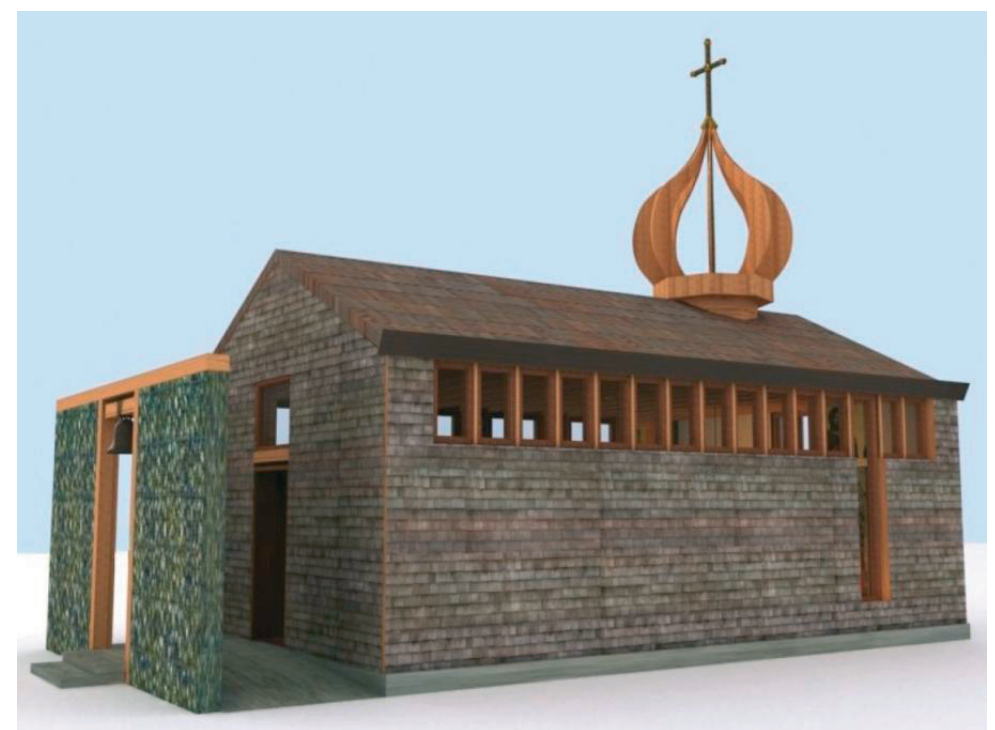

Rys. 6. Czasownia (kaplica) projekt studialny. Autor: mgr inż. arch. Wojciech Mielnik

Jednym z najbardziej znanych współczesnych drewnianych obiektów sakralnych jest kaplica w Tarnowie nad Wisłą. Obiekt ufundowany został przez osiedlonego w tej okolicy pisarza, wzniesiony większości sposobem gospodarczym przy udziale miejscowej ludności. Ulokowany jest na osi północ-południe na wzgórzu u podnóża Wisły. Ma konstrukcję ramową z belek na połączenia ciesielskie. Bryła budowli charakteryzuje się uproszczoną formą. Wykończenie północnej ściany stanowi licowane deskowanie z głównym wejściem na osi. Elewacja i dach pokryte są wiórem osikowym. Na południowej elewacji znajduje się jedyne w obiekcie duże przeszklenie, które otwiera się na dolinę Wisły.

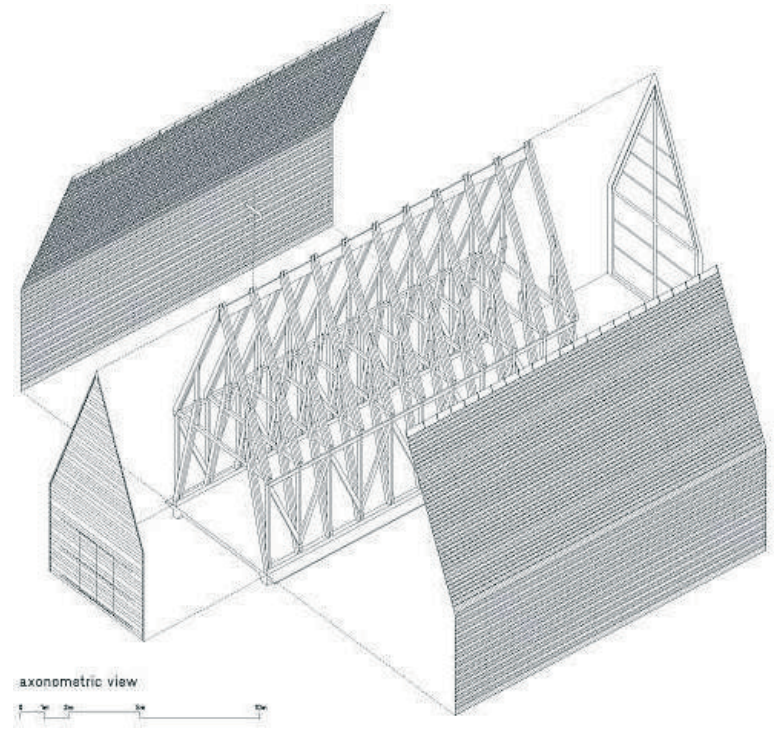

Rys. 7. Kaplica w Tarnowie, Autorzy: Grupa Beton

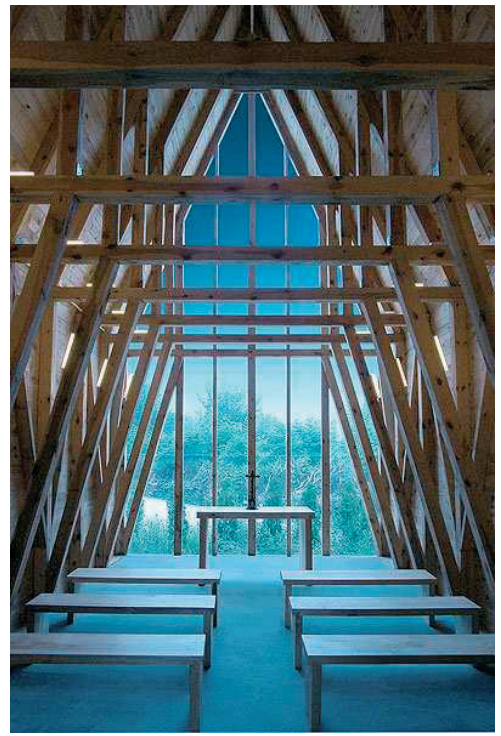

Rys. 8. Aksonometria, Autorzy: Grupa Beton 


\title{
5. Wnioski
}

Obiekty wernakularne zapisane w przestrzeni budują obraz minionych czasów. Takie zapisy mają ogromne znaczenie dla ciągłego kształtowania tożsamości miejsca oraz żyjących w nim ludzi. Mając na względzie dobro przyszłych pokoleń, musimy włożyć maksymalny wysiłek nie tylko w zachowanie drewnianego dziedzictwa, ale również zachęcać do popularyzacji tradycyjnych form budownictwa, które stanowi także determinantę i punkt odniesienia dla twórczej kreacji współczesnych architektów. Obecnie w światowej architekturze dostrzec można silną tendencję powrotu do architektury znaczeń zakorzenionej w drewnianej tradycji. Objawiają się ona w nurtach regionalizmu będących reakcją na wszechobecną unifikację wzorców oraz ogarniającą nas globalizację.

\section{Literatura}

1. Mielczarek Z. Budownictwo drewniane. Wydawnictwo „Arkady”, Warszawa 1994.

2. Żenczykowski W. Budownictwo ogólne Tom III. Wydawnictwo BA, Warszawa 1956.

3. Michniewicz W. Konstrukcje drewniane. Wydawnictwo „Arkady”, Warszawa 1958.

4. Fraścika F. Cieśla stolarz dekarz. Zakład Budownictwa Wiejskiego PWT, Warszawa 1950.

5. Kopkowicz F. Ciesielstwo polskie. Wydawnictwo „Arkady”, Warszawa 1958.

6. Kozarski P. O konserwacji budownictwa. Dyrekcja Generalna Lasów Państwowych, Warszawa 2014.

7. Civilingenior Hilmer Riberholt (thum. Fleks A.). Drewno klejone. Lilleheden, Gdynia 2002.

8. Tłoczek I. Polskie budownictwo drewniane. Wydawnictwo Zakład Narodowy im. Ossolińskich, Wrocław 1980.

9. Ruszczyk G. Drewno i architektura. Wydawnictwo Arkady, Warszawa wydanie II 2014.

10. http://www.archdaily.com/39747/chapel-in-tarnow-beton/, aktualne na dzień 2009.11.18

\section{Wooden construction in sacral architecture in the past and today}

\section{Wojciech Mielnik}

Faculty of Architecture, Gdańsk University of Technology,e-mail: wojciech.mielnik@qplan.pl

\begin{abstract}
The wooden sacral architecture has had a great importance for the development of construction and aesthetic values. Rooted in the tradition focuses all the features of human existence as spirituality, culture, technology materialized using the best materials and the knowledge and skills "spirituality covered with wood." Objects stored in the vernacular build a picture of past times, as well as the shapes identity of the place and the people living in it. They are the determinant and a reference point for creative creations of contemporary architects. Development of wooden structures allows for increasingly bold application. Contemporary examples of temples show a variety of forms using a large variety of types of construction giving unlimited possibilities.
\end{abstract}

Keywords: wood, construction, sacral objects, church. 
